\title{
Entrepreneurship and the legal form of businesses: The role of differences in beliefs
}

\author{
OSCAR GUTIÉRREZ \\ Universidad Autónoma de Barcelona \\ Pedro OrTín-Ángel \\ Universidad Autónoma de Barcelona
}

\begin{abstract}
Entrepreneurship has been considered a way to implement interpersonal authority, i.e., to convince other persons to use their resources in an alternative way to the optimal one in accordance with their beliefs. This paper presents a theoretical model that relates the above assumption with the following two questions: (i) how and why financial constraints can prevent the implementation of entrepreneurial projects; and (ii) how creditors' priorities provided by the different legal forms of the business can reduce the financial requirements for implementing the firm. The attractiveness of such an explanation lies in its capacity to justify a wide array of features of firms (entrepreneur origin, property rights, authority, financial constraints and creditor priorities) from a single basic assumption: agents have different beliefs about how production should be organized.
\end{abstract}

Keywords: Entrepreneurship, Beliefs, Credit Constraints, Creditors’ priorities, Legal form.

JEL Classification: D23, L21, L22. 


\section{Introduction}

For decades, the legal form of productive organizations and who assumes the role of entrepreneur have been taken as given by the economic literature. However, such questions can be considered as a part of the decision set from which the economic agents can choose. In fact, this is at the root of research fields like organizational law and entrepreneurship. Recently, economists have addressed such kinds of questions. One of those contributions is the concept of interpersonal authority and its relation with entrepreneurship (Van den Steen, 2010).

This paper goes one step further by relating interpersonal authority to the financial problems usually associated with new firms. A theoretical model is developed for understanding the role of differences in beliefs in the creation of a new firm, as well as how they are related to the entrepreneur's financial problems, and the choice of the legal form. The model assumptions fit quite well with the "creative destruction” view of the entrepreneurs' role in the economy, as persons that break the initial equilibria with path-breaking ideas about how inputs can be combined (Schumpeter, 1939).

In the model, a new productive activity competes with old ones for the access to a certain amount of resources, i.e., inputs. Those resources come from the wealth that people invest based on their inter-temporal consumption preferences. The only distinction among productive activities is the confidence level that persons have in these projects, i.e., the beliefs from which the results of the activities are computed. So, the projects that we consider require the same amount of inputs (or total financial support).

Let us call the person (or group of persons) who is more confident concerning the new productive activity (whenever production is organized following that person's instructions) entrepreneur, and assume that the entrepreneur needs financial support. In other words, for the entrepreneur it is (a priori) optimal to invest less money than the 
total financial support required for developing the new productive activity. According to people's inter-temporal consumption preferences, a priori there is an optimal ratio of internal (entrepreneur) vs. external (others) funding for the new productive activity.

Based on differences in beliefs, the model shows that when the rest of the people involved (stakeholders) have higher confidence in other productive activities (than in the new productive activity), the entrepreneur has to divert resources from consumption to investment in order to develop (fund) the new productive activity. In this context, capital is the monetary value of the minimum amount of resources that the entrepreneur has to divert from consumption to investment in order to develop the new productive activity. Assume that the wealth of the entrepreneur is high enough. Then, the new productive activity will be developed whenever the opportunity cost of capital is lower than the expected profits of the new productive activity. In this case, the ratio of internal resources to external ones will be higher than the a priori optimal one (the established one when all people involved have the same beliefs as the entrepreneur).

We compare the capital needed in two different contractual arrangements. In the first one, the entrepreneur initially advances certain payments to the creditors. In the second, the entrepreneur postpones consumption (to some extent) and establishes a public list of creditors' priorities over the capital and the output finally obtained in the production activity. We show that the need of capital is reduced when, in the list of creditors, the order of priority decreases with the creditors' confidence in the project.

To the best of our knowledge, no model with basically one exogenous variable (which in our case consists of differences in beliefs) has endogenously established:

(i) Who will decide the use of certain inputs (entrepreneur) against alternative uses suggested by other persons (authority); 
(ii) That all of the stakeholders agree that the entrepreneur will have the residual claims of the productive activity;

(iii) That (when differences in beliefs are severe) the entrepreneur has to anticipate capital in order to assure the project's development, and

(iv) That the existence of a public list of creditors' priorities for developing such activities reduces the volume of capital needed.

To some extent the model analyzes decisions that become keys in several streams of the economic literature: entrepreneurship, theory of the firm, finance, and organizational law. The following section relates the model, and its main assumptions, with these streams of the literature. Model assumptions are formally stated in Section 2. The need of capital is derived in Section 3, and the role of payments priorities is analyzed in Section 4. The empirical implications of the model are discussed in Section 5. Section 6 presents some conclusions and extensions.

\section{Related literature}

\subsection{Differences in beliefs}

“A large fraction of the founders and chief executives (...) indicated that they had a specific organizational model in mind” (Baron, Burton and Hannan, 1999, p. 5). The assumption that people can agree to disagree is also implicit in the terms of Vision (See Rotemberg and Saloner, 2000, p. 693-695 for more references), The Theory of the Business (Drucker, 1994) or Upper Echelons Reflections (Hambrick and Mason, 1984) among others. These are just examples that this assumption is well-accepted in the managerial literature.

This is not so common among economists; "the consensus of the profession in these respects is clear (...). Models in which agents have different priors allow 
sufficient freedom as to be capable of generating virtually any outcome, while providing such insights as different agents behave differently because they have different beliefs" (Samuelson, 2004, p. 377). So, the standard assumption based on Auman's (1976) "state-pace” model of knowledge (see Samuelson, 2004, for a review) is that people cannot agree to disagree. Obviously, this last conclusion is obtained under the assumption that people have the same prior beliefs, and that the probability of an event is common knowledge. Kurz (1994 a, b) shows that rational individuals can have different beliefs even if they have observed the same historical evidence when they have different prior beliefs. Some empirical evidence has been interpreted in favor of the fact that differences in beliefs do exist. Parker (2006) provides empirical evidence suggesting that entrepreneurs update their prior beliefs to new information much more slowly than is theoretically expected. Bertrand and Schoar (2003) provide evidence that managers have a significant effect on the way that firms are organized and on their performance. Moskowitz and Vissing-Jorgensen (2002), by investigating the poor performance of investment in non-publicly traded U.S. equity, show that entrepreneurs may well have different business models in mind. Finally, the existence of markets with speculative components can be interpreted as evidence of the existence of different beliefs.

Therefore, we cannot ignore the fact that these differences in beliefs can exist. Our proposal is to analyze the optimal contractual arrangements by simply assuming that there are differences in beliefs regarding the optimal production activities, and assuming nothing else about the nature of those beliefs. This is the approach followed in Van den Steen (2010a, 2010b, 2005). 


\subsection{Entrepreneurship and the theory of the firm}

We consider "the entrepreneur" as the person (or set of persons) who starts a firm. This definition of entrepreneur is quite close to earlier ones (e.g., Cantillon, 1755), but almost three centuries of literature have provided many other meanings. Following Casson (2010), "two main ways of defining entrepreneurship can be found in the literature. One defines the entrepreneur as the founder or owner-manager of a small- or medium-size enterprise (SME) with growth potential, whilst the other defines the entrepreneur in terms of the economic function that he or she performs”. It is far from our purpose to revise such definitions, but we must note that the paper's contributions are conditioned by our definition of entrepreneur. Moreover, for identifying what an entrepreneur is, we need to define what a firm is.

Hansmann and Kraakman (2000) consider a well-defined decision-making authority and its ability to bond its contracts credibly as main attributes of a firm. We follow Van den Steen (2010a) quite closely for understanding and modelling decisionmaking authority. In fact, we extend his analyses in order to understand how the firm bonds its financial contracts credibly. The model builds upon a simplified version of Van den Steen (2010a). In fact, we reproduce the basic results related to interpersonal authority. In the terms of Van den Steen (2010a, p. 466), “one person has interpersonal authority over another if: (i) the first person tells the second what to do, ii) the second person tends to act in accord with these instructions, and iii) he often does so against his own beliefs or immediate preferences". He shows that more confident persons will not only have this authority; they will also be the asset owners and the residual claimants of the production activity or firm.

So entrepreneurs assume risk (or in other terms, residual claims) even if there are no differences in risk aversion among the population. Note that only by assuming 
differences in people's attitude towards risk, it has been very difficult to explain interpersonal authority. In Van den Steen (2010a), the main driver for being an entrepreneur is the relatively high degree of confidence of one person in a particular entrepreneurial project. Then, and this feature contrasts with other explanations of entrepreneurship, the person who assumes the role of entrepreneur does not need to be more self-confident independently of the project selected, nor more optimistic independently of who develops a project. However, more optimistic or self-confident persons will be more confident in the entrepreneurial project developed. Obviously, other reasons (such as knowledge or professional experience) could be behind differences in entrepreneurial projects confidence. We will just assume that they exist, without analyzing where they come from or the past experience of the entrepreneur.

There are other theories of the firm (see Gibbons, 2005, for a summary). But although the described features are not necessarily the only ones, they seem to be among the defining features of a firm, at least for some literature. In Williamson's (2000) terms, unified management is a necessary part of being a firm. This concept is quite similar to the interpersonal authority modeled by Van den Steen (2010a), where the entrepreneur is associated with the person that exerts this authority. Property rights theory usually argues that authority is conferred by ownership of an asset (Grossman and Hart, 1986, and Hart and Moore, 1990), but this claim is not fully explained by the property rights theory; see Hermalin (1999). Moreover, differences in beliefs offer an alternative explanation as to why a formal authority arises and is allocated at the top of the hierarchy, something consistent with the idea of "centralization of decisionmaking”, suggested by Hermalin (1999) and Williamson (2000) as a defining feature of the firm. The ownership of assets is a way to implement such authority, as it can work 
as a lever to better influence workers' incentives (Holmstrom, 1999). Van den Steen (2010a) presents a detailed discussion of differences with other theories of the firm.

\subsection{The firm's financing}

The model contrasts with Van den Steen (2010a) in placing stress on financial concerns. A diverging feature (also diverging from other models like that of Hart and Moore, 2005) is that Van den Steen (2010a) deals with the initial discrepancies regarding the optimal use of inputs rather than with the probabilities of new, future ideas. In particular, he considers the possibility of future differences in beliefs regarding how assets should be prepared for production, but once they are ready to start producing, all team members agree about how that production should be organized. Therefore, from the beginning, all payments to which the entrepreneur/owner is committed will be lower than the expected team production. In contrast, in our model the differences in the agents' confidence on the finally developed entrepreneurial project persist. So, from the very beginning some agents will require payments or guarantees of payment, and initial capital is required from the entrepreneur.

"Perhaps, the most frequently cited obstacle to business formation is the inability of would-be entrepreneurs to acquire the capital necessary to start a business” (Hurst and Lusardi, 2004, p. 20). Indeed, much literature has documented a positive relationship between initial wealth (or inheritances received in the past) and subsequent entry in business. ${ }^{1}$ So we will assume that people are wealth-restricted.

The need for financial support in order to finance entrepreneurial projects is endogenously derived in our model. This need for financial support is exogenously 
imposed in models like those of Boot et al. (2006), Dittmar and Thakor (2007) or Boot and Thakor (2011). These papers analyze how differences in managers' and investors' beliefs might affect stock prices, and then the decision to issue equity in the market as opposed to other alternative financial mechanisms, private ownership or debt.

The need for financial support is instead endogenously derived in De Meza and Southey (1996), but differs from our argumentations in several aspects. First, we assume that people can have different levels of confidence about the outcome of the projects. Second, De Meza and Southey (1996) analyze the decision to become an entrepreneur in terms of the degree of personal optimism and wealth. Optimists always overestimate the real distribution of earnings and, consequently, they are willing to pay more than the expected returns (when optimists become entrepreneurs, the actual expected returns of firms are always negative). As our starting point is the existence of differences in beliefs, nothing is established a priori about how realistic the predictions are, and nothing is assumed about the true distribution of returns.

There are other differences with De Meza and Southey (1996). As is common in the financial literature (Fan and White, 2003, or Evans and Jovanovic, 1989), they basically focus on an analysis of the relation between entrepreneurs and a bank with unlimited funds, so how are those funds provided is not analyzed. Furthermore, they do not take into account the fact that the entrepreneur contracts employees, so the decision to become an entrepreneur is not related to other people's decisions to become employees. Since they do not take this relationship into account, nothing can be said about firms’ internal organization. Following Evans and Jovanovic’s (1989) arguments, initial wealth plays the role of collateral and limits the entrepreneur's capacity to

\footnotetext{
${ }^{1}$ See, for example, Blanchflower and Oswald (1998); Evans and Jovanovic (1989); Evans and Leighton (1989); Fairlie (1999); Holtz-Eakin et al. (1994); Quadrini, (1999); Paulson and Towsend (2004) and Paulson et al. (2006).
} 
borrow. Aghion and Bolton (1997) offer an explanation for the need for such collateral: entrepreneurs' actions cannot be observed by borrowers until the project fails and consequently payments are unfeasible. As a result, poor borrowers have little incentive to be diligent, and lenders charge higher interest rates to less wealthy borrowers. Collateral and self-financing help to solve the problem and this reduces the interest rate of the loan. We offer an alternative explanation for the need for such collateral or selffinancing when lenders can perfectly supervise the borrower's actions. Collateral is claimed by those stakeholders who believe that the payments committed by the entrepreneur are larger than the firm's future income, and the firm will not be established if entrepreneurs cannot offer enough collateral to guarantee future payments. In such a case, and unlike De Meza and Southey (1996), potential workers could finally become entrepreneurs. All of these models remain silent concerning the role of creditors’ priorities.

\subsection{Firm legal form}

Some authors (Robé, 2011) claim that there is some confusion in the economic literature, mainly in the agency and property rights theory, between firms and corporations. "Corporations are a subset of firms (...). A corporation is characterized by a statement of capital contributions as formal claims against the firm's income (...). Equity investors are paid last, after debt investors, employees, and other investors with (relatively) fixed claims (...). The corporation is a financing device and is not otherwise distinctive. Sometimes, it is said that the distinctive features of the corporation are limited liability, legal identity, and perpetual existence, but these are misleading descriptions” (Easterbrook and Fischel 1989, p. 1425-6). 
According to Hansmann and Kraakman (2000), an essential role of organizational law is the so-called "asset partitioning" separating those assets of the firm from the assets of the owner or managers. "The truly essential aspect of asset partitioning is, in effect, the reverse of limited liability- namely, the shielding of the assets of the entity from claims of the creditors of the entity's owners or managers" (p. 390). They call this feature "affirmative" asset partitioning in order to differentiate it from the "defensive" asset partitioning. "Defensive” asset partitioning is mostly related to limited liability; the firm creditors are excluded from making a claim on the owner's assets in case of firm default. Only the "affirmative” asset partitioning is considered essential by the authors: "it would generally be infeasible to establish this form of asset partitioning without organizational law; and (...) this attribute -essentially a property attribute- is the only essential contribution that organizational law makes to commercial activity, in the sense that is the only basic attribute of a firm that could not feasibly be established by contractual means alone” (p.393). A historical analysis of the evolution of the organizational law supports such analyses (Hansmann and Kraakman, 2006).

The main contribution of our model to this literature is to emphasize a new advantage of affirmative partitioning, in particular how the amount of money needed by the entrepreneur to establish a firm can be reduced. For formalization convenience, we do not consider the existence of personal creditors of the entrepreneur, so "defensive" asset partitioning, mostly related to limited liability, is omitted from the analysis. We do not claim that this feature (limited liability and, in general, the protection of personal creditor rights) is irrelevant, but we do not try to argue regarding the distinctive features of the organizational law. Here, it is only claimed that for some authors the firm's creditors' priorities concerning the firm's assets is among the most important ones, and the model illustrates an advantage of having a list of creditor priorities. 
For expositional simplicity, the model only considers one productive input that we identify with labor. Thus, we speak of market solution when productive activities are taken by one person alone, while firm describes the situation where workers are contracted for developing productive activities. ${ }^{2}$ In this last case, and following the discussion above, when there is a list of creditor priorities, we will speak of corporations; otherwise we speak of sole proprietorship. Although this classification does not exhaustively address all of the possible business legal forms, it does cover the most important ones. According to the Internal Revenue Service of the US Department of the Treasury, there were 27,757,676 businesses in the US in 2007. Only 6,049,655 of those have establishments with employees, of which 4,267,818 were corporations and 627,549 partnerships, while 1,071,873 were sole proprietorship. Most of the firms without employees are sole proprietorships. ${ }^{3}$ This composition is similar to that of other countries.

Furthermore, the model takes into account the main arguments for the incorporation of a firm suggested by Arruñada (2012), the comparison of bureaucratic costs with the profits from being registered. We consider that a main difference between legal forms is their capability to protect the firm's creditors and establish priorities among them. A corporation helps protect those creditors related to the entrepreneurial activity better than to a sole proprietorship, but at higher bureaucratic costs. The model does not analyze how the bureaucratic costs are related to creditor protection given that

\footnotetext{
${ }^{2}$ Strictly speaking, our model does not distinguish among productive inputs. So what really distinguishes a firm from the market solution is purchasing inputs to other persons for productive activities. In this sense our model fits better as a "theory of the firm" (it provides an explanation for the creation of firms) than as a "theory of the entrepreneur" (for the model, there are two kinds of self-employed persons: those in the "market solution" vs. "firm owners").

3 19,089,091 accordingly with the US Census Bureau, while 1,428,932 were corporations and 1,189,998 partnerships.
} 
the purpose of the paper is not to analyze the adoption of a certain legal system. The model is centered on firms’ decisions after a legal system has been established.

The predictions of the model and the empirical evidence go against the standard financial life-cycle theory of the firm (Fama and Jensen, 1983a,b), whereby a firm starts out as a proprietorship and then changes to a partnership or corporation as it grows and needs financing. Based on the Kauffman Firm Surveys data sample, Cole (2011) shows that only one-third of firms began as sole proprietorships, which are almost as many as corporations. Similar figures are found for the UK (Frankish et al., 2013) and other European countries. ${ }^{4}$ Furthermore, only $10 \%$ of firms changed their legal form during their first four years of life, most changes occurring in the early years. In fact, the existing evidence shows that the legal form is related to the firms' financial decisions. Corporations have more access to bank financing (Storey, 1994) and higher growth rates (Storey, 1994; Harhoff et al., 1998).

\section{Model assumptions}

In this section the model's assumptions are presented. We develop two versions of the model which basically differ in the population configuring the economy. The first version considers a two-person world, reproducing the Van den Steen (2010a) main effects of differences in beliefs on entrepreneurship, and its relationship with the internal organization of a firm, i.e., (1) the allocation of formal authority and (2) the distribution of output. The present paper contrasts with Van den Steen (2010a) in its stress on financial concerns. The owner's need for financial support in order to develop

\footnotetext{
${ }^{4}$ See Business Demography Statistics provided by Eurostat. http://epp.eurostat.ec.europa.eu/portal/page/portal/european_business/special_sbs_topics/business_demography
} 
entrepreneurial projects is endogenously derived in our model. The second version of the model analyzes how creditors' priorities affect the amount of financial support needed by the owner for the establishment of the firm.

\subsection{Agents' preferences}

Persons live two periods $(0,1)$. At Period 0 each person $i$ is endowed with some resources whose monetary value is their initial wealth $\left(A_{i}\right)$. This wealth can be shared between production and consumption activities. The amounts dedicated to production activities are $\left\{l_{i}\right\}$. In Period $0, l_{i}$ represents the assets in the economy provided by Person $i$ for productive activities. In other words, $l_{i}$ is the availability for financing productive activities by Person $i$. This amount could be cash, goods, or time. For expositional purposes, we assume that this last input is the case; $l_{i}$ represents the monetary value assigned to the leisure time which is sacrificed in production activities (i.e., the opportunity cost of working). Then, the amount of money available for Person i's consumption at Period 0 will be $A_{\mathrm{i}}-l_{\mathrm{i}} \equiv m_{\mathrm{i}}$.

For simplicity, let us assume that it is not in the interest of the persons to take lending/borrowing activities for consumption purposes. In other words, $m_{i}$ can be considered the amount of money available for Person i's consumption at Period 0 when the financial market is in equilibrium. It is far from our purpose to model such equilibrium, but we assume that deviances will have costs. If Person $i$ deviates from the equilibrium by lending $k_{\mathrm{i}}$ to Person $-i$ at Period 0 , they incur in a social cost of $\mathrm{R} k_{\mathrm{i}}$, where $\mathrm{R}$ is a non-negative constant denoting the costs per monetary unit of such a deviation. In our model, $k_{\mathrm{i}}$ will be positive only when it is strictly needed for establishing a productive activity that is in the interest of Person $i$ (detailed in the next section). So, it is expected that this person will assume all of the social cost $R k_{\mathrm{i}}$. In fact, 
the agent who assumes the social costs becomes irrelevant when the analyses are based on the expected social welfare, as we assume. The initial wealth limits such payments: $k_{\mathrm{i}} \leq A_{\mathrm{i}}-l_{\mathrm{i}} \equiv m_{\mathrm{i}}$.

At Period 1, persons only consume the output that production activities generate. Let $w_{\mathrm{i}}$ be the monetary value of expected output appropriated by Person $i$. Then, the welfare increase (utility) obtained from production activities by Person $i$ can be written in monetary terms as:

$$
u_{i} \equiv w_{\mathrm{i}}-l_{\mathrm{i}}-\mathrm{R} k_{\mathrm{i}}
$$

See Appendix I for further discussion on the financial market equilibrium and how this utility function can be derived from a more general inter-temporal utility function in such equilibrium. Our point is merely that changing this financial equilibrium $\left(k_{\mathrm{i}}>0\right)$ has an opportunity cost $\left(\mathrm{R} k_{\mathrm{i}}>0\right)$.

\subsection{Production activities}

All of the production activities at Period 0 require the same volume of financial support, , but they can provide different production levels at Period 1. The economy production $q$ will be the result of the set of actions $a^{i}$ that each Person $i$ makes with input $l_{\mathrm{i}}$. Those actions can be summarized by a vector $a=\left(a^{1}, \ldots, a^{i}, \ldots\right)$. Persons can have different beliefs due to different predictions about future output given those actions. Function $\hat{q}_{i}(a)$ summarizes such beliefs. For the sake of tractability, let us assume that, based on their beliefs, there are only three possible types of persons ${ }^{5}(i=E$, $W, W_{1}$ ). Then, we restrict the analysis to just three vectors of actions (later on, we relax

\footnotetext{
${ }^{5}$ For exposition purposes, we assume that $\mathrm{E}$ is a woman and Ws are men.
} 
this assumption) or alternative sets of production activities, the ones that each type of Person $i$ believes they are the optimal ones: $a_{i}=\arg \max \left(\hat{q}_{i}(a)\right)$, so $\hat{q}_{i}\left(a_{i}\right) \geq \hat{q}_{i}\left(a_{j}\right)$.

The case where production is developed without collaboration between the agents will be considered as the benchmark situation, $a_{\mathrm{W} 1}=\left(a_{\mathrm{W} 1}{ }^{1}, \ldots, a_{\mathrm{W} 1}{ }^{i}, \ldots\right)$. In other words, $\mathrm{W}_{1}$ does not know how to improve past outputs. Everybody agrees that the expected output that Agent $i$ obtains by making use of his own time is $l_{\mathrm{i}}$, so $\hat{q}_{i}\left(a_{W 1}\right)=\hat{q}=\sum_{i} l_{i}$, and $\sum_{i} u_{i}=0$

This situation can be considered as a benchmark situation in the sense that it can represent an economy in equilibrium. From that point of view, persons with potentially new ideas may appear; in our case, Persons E and W. Entrepreneurs have been described in the literature as persons that break initial equilibrium with path-breaking ideas about how inputs can be combined (Schumpeter, 1939). These ideas are captured by assuming that agents can have different beliefs about the best use that can be given to the productive assets, for example, agents' time.

Consider now the second production activity, $a_{\mathrm{E}}=\left(a_{\mathrm{E}}^{1}, \ldots, a_{\mathrm{E}}^{i}, \ldots\right)$. Using Van den Steen's (2010a) terminology, we define this activity as Persons E’s interpersonal authority. The idea is that Persons E need to convince somebody $j$ to change his preferred actions. Then, Persons E do not agree with $\mathrm{W}_{1}\left(a_{\mathrm{E}}^{\mathrm{E}} \neq a_{\mathrm{W} 1}{ }^{\mathrm{E}}\right)$, and want others to follow their instructions: for somebody $j, a_{\mathrm{E}}^{j} \neq a_{\mathrm{w} 1}^{j}$. For the sake of simplicity, from now on let us assume that for all of the population, $a_{\mathrm{E}}{ }^{i} \neq a_{\mathrm{W} 1}{ }^{i}$ (in other words, we restrict the analysis to the set of persons fulfilling the last condition). Person E believes that the output obtained will be $\hat{q}_{E}=\hat{q}_{E}\left(a_{E}\right)$, a measure of E's self-confidence in their own projects. 
A third production activity is $a_{\mathrm{W}}=\left(a_{\mathrm{w}}{ }^{1}, \ldots, a_{\mathrm{w}}{ }^{i}, \ldots\right)$. We call this activity Persons W interpersonal authority. The only difference with the case above is that we assume that Persons $\mathrm{W}$ are less confident in their own ideas than is $\mathrm{E}$ in hers, i.e., they have less self-confidence in their projects. In formal terms, they believe that the output obtained will be $\hat{q}_{W}=\hat{q}_{W}\left(a_{\mathrm{W}}\right)$, with $\hat{q}_{W}<\hat{q}_{E}$.

For the derivation of our results, all that we need is that agents have different degrees of self-confidence in their projects. In order to make it clear that our results are not reduced to the case where one agent is more optimistic than the others, we assume that Persons E are not more optimistic than Person W: $\hat{q}_{W}=\hat{q}_{W}\left(a_{\mathrm{W}}\right)>\hat{q}_{E}\left(a_{\mathrm{W}}\right)$. Figure 1 summarizes the variables used in next sections. We also assume that all the expected results are publicly known. It does not mean that the internal ways in which beliefs are built up by agents are public information, but rather only their effects on expected outputs.

Figure 1. Output predictions for different production activities

Production activities

\begin{tabular}{|c|c|c|c|c|}
\hline $\mathbf{P}$ & & $\begin{array}{c}\text { No Collaboration } \\
a_{\mathrm{w} 1} \\
\end{array}$ & $\begin{array}{c}\text { E interpersonal authority } \\
a_{\mathrm{E}} \\
\end{array}$ & $\begin{array}{c}\text { W interpersonal authority } \\
a_{\mathrm{W}} \\
\end{array}$ \\
\hline $\begin{array}{l}\mathbf{R} \\
\mathbf{E} \\
\mathbf{D}\end{array}$ & Persons E & $\hat{q}$ & $\hat{q}_{E}$ & $\hat{q}_{E}\left(a_{\mathrm{W}}\right)$ \\
\hline $\begin{array}{l}1 \\
C \\
T\end{array}$ & Persons W & $\hat{q}$ & $\hat{q}_{W}\left(a_{\mathrm{E}}\right)$ & $\hat{q}_{W}$ \\
\hline $\begin{array}{l}1 \\
\mathbf{O} \\
\mathbf{N}\end{array}$ & Persons W1 & $\hat{q}$ & $\hat{q}_{W 1}\left(a_{\mathrm{E}}\right)$ & $\hat{q}_{W 1}\left(a_{W}\right)$ \\
\hline
\end{tabular}

In Appendix II, we relate our modeling with the probabilistic model of differences in beliefs developed by Boot et al. (2006) and Van den Steen (2010a). An important difference with Van den Steen (2010a) is that differences in beliefs persist even when assets are already available for production. In fact, in such models 
contractual arrangements are developed in prevision of future disagreements, while our model is based on current disagreements about the results of a particular project. Appendix II also analyzes the difference between beliefs and risk aversion, and the implications for the analysis of authority.

\subsection{Institutional Arrangements: Contracts and costs}

At Period 0, persons make arrangements and actions are taken with the inputs available (time, $\left.l_{\mathrm{i}}\right)$. At Period 1 , output $(q)$ is obtained. Actions and production are observable and publicly known (and therefore contractible) at the beginning of Period 0, before production activities are implemented.

Therefore, different kinds of agreements can arise:

a) Market. Persons take decisions on production activities with their input factors (time): everybody chooses what to do with their own assets. The output obtained by Person $i$ is the income obtained at Period 1, $w_{\mathrm{i}}$. Proprietorships without employees appear. In this case, the vector of actions $a_{\mathrm{W} 1}$ is implemented. This solution can be associated with the market solution; see Easterbrook and Fischel's (1989) terminology. In fact, we are going to assume that when a vector of actions can be implemented by the market, this arrangement will be the most efficient one for implementing such vector of actions. For example, a person can contract other persons to perform actions $a_{\mathrm{W} 1}$, paying them amount $w_{i}=\hat{q}_{i}\left(a_{W 1}^{i}\right)=l_{i}$. We assume that writing such contracts has a small (negligible) cost. Thus, the market is the most efficient arrangement to implement the vector of actions $a_{\mathrm{W} 1}$.

b) Firm: Interpersonal authority. The production activities $a_{\mathrm{E}}$ or $a_{\mathrm{W}}$ are implemented. Persons (-i, workers) have to decide whether to use their inputs $\left(l_{-i}\right)$ according to Persons $i$ (entrepreneurs) beliefs or according to their own beliefs ( 
$a_{i}^{-i} \neq a_{-i}^{-i}$, workers). The way to convince those persons is through a contract signed at Period 0. We identify “firm” with those contracts, which must establish:

b1) Authority over the inputs: Entrepreneur. Which actions ( $a_{\mathrm{E}}$ vs. $a_{\mathrm{W}}$ ) will be adopted? b2) Output property rights. How is output $q$ (value created by the firm) shared by the agents?

We restrict our analysis to linear "sharing contracts" based on the (ex-post) output. For example, we rule out situations in which $i$ offers - $i$ a certain salary for taking actions $\left(a_{i}\right)$ if the final output is $\hat{q}_{-i}\left(a_{i}\right)$, and zero otherwise. ${ }^{6}$ Then, income $w_{\mathrm{i}}$ obtained by Person $i$ at Period 1 is:

$w_{\mathrm{i}}=s_{\mathrm{i}}+p_{i} q$,

where $s_{\mathrm{i}}$ represents the payment received from $\left(s_{\mathrm{i}}>0\right)$ or paid to the other agents $\left(s_{\mathrm{i}}<0\right)$. The variable $p_{i}$ represents the share $\left(0 \leq p_{i} \leq 1\right)$ of the team wealth (output) received by person $i$, so $\sum_{i} p_{i}=1$.

b3) Entrepreneur financing: Corporation vs. Sole-proprietorship.

For the establishment of the firm, it could be the case that the entrepreneur has to advance in Period 0 more money than that initially required $\left(k_{\mathrm{i}}>0\right)$. Two ways of providing this amount of money can be considered: Sole-proprietorship and Corporation. In the case of a Sole-proprietorship, $k_{\mathrm{i}}$ is simply the payments made at Period 0 . In the case that, at the beginning of the relationship a corporation is created, $k_{\mathrm{i}}$ represents the capital of the corporation. In this case, $l_{\mathrm{i}}$ can be considered as the owner's contributions to the Corporation which are not in the balance sheet. At Period 0 , the Corporation's balance sheet specifies the assets, $l_{-\mathrm{i}}$, and how they have been financed:

\footnotetext{
${ }^{6}$ This fact would represent a bet on the ex-post output, and the assumption we make is fairly close to the no-gambling constraint in Meza and Southey (1996) or Van den Steen (2007). Furthermore, the model in the text can be considered to be a simple version of a more complex one, where "betting contracts" are inefficient because they induce undesirable behaviors in workers (See Appendix III for further details).
} 
corporation capital, $k_{\mathrm{i}}$, and liabilities $\left(l_{-\mathrm{i}}-k_{\mathrm{i}}\right)$. For simplicity, let us call $k_{\mathrm{i}}$ the firm's capital.

The difference is that corporation laws establish the creditors' priorities in the liquidation of the firm, i.e., ways of distributing the output and the firm's capital are established. In the case of sole-proprietorship, such a list of creditor priorities is more diffuse, if it exists at all (for a further discussion, see Hansmann and Krakmann, 2000, specially p. 407-409). The existence of this list of creditor priorities could affect (or not) the amount of capital that the entrepreneur must advance at Period 0. We can identify $d$ with the difference in capital needs between sole-proprietorship firms and corporations.

Arruñada (2012, p.161-167) argued that those guarantees are not free, so corporations are expected to have higher bureaucratic costs $c \geq 0$ (mainly related to the registry procedures associated with the legal form of the firm). ${ }^{7}$ Corporations will be established if $\mathrm{R} d>c$. For the sake of simplicity, we assume that bureaucratic costs are small, $c \approx 0$ (later on, we relax this assumption). So in this model, a necessary condition for establishing a Corporation is that it reduces the capital needs required for developing a certain entrepreneurial project, $d>0$. Figure 2 summarizes the possible contracts and their denominations.

\section{Figure 2. Contractual Nomenclature}

\begin{tabular}{l|c}
\hline $\begin{array}{c}\text { Market Solution: } \\
\text { There are no employees. }\end{array}$ & $\begin{array}{c}\text { Firm: } \\
\text { There are employees (Formal Authority) }\end{array}$ \\
\hline & $\begin{array}{c}\text { Firm legal form: } \\
\text { Sole proprietorship: } \\
\text { No affirmative asset partitioning. }\end{array}$ \\
& $\begin{array}{c}\text { Cntrepreneurial creditors have no specific protection. } \\
\text { Corporation: }\end{array}$ \\
& Affirmative asset partitioning. \\
& Capital and creditor priorities \\
\end{tabular}

7 It could be argued that, depending on the firms, the Corporation tax treatment is different, so for some firms $\mathrm{c}<0$ and that explains the incorporation of those firms. We do not consider this case. 
Following the terminology of Easterbrook and Fischel (1989, Section II) and Hansmann and Kraakman (2000), see Table 1.

It must be noted that corporations without employees have not been explicitly considered as a possible arrangement. It is easy to see that this kind of arrangement arises if we reinterpret $l_{i}$ as a productive input different from labor.

\subsection{Different model versions based on population composition}

For the sake of illustration, two model versions are presented here that differ in the population that configures the economy. In the first case only two persons exist, $\mathrm{E}$ and W. This is a simplifying way to say that in an economy in equilibrium two competing entrepreneurial ideas for using the same volume of resources appear. So by $\mathrm{E}$ we identify the set of persons (with the same beliefs) which are more self-confident in their entrepreneurial idea. From the rest of the population, we identify by $\mathrm{W}$ the set of persons (with the same beliefs) who are more confident in E's entrepreneurial idea. Persons $\mathrm{W}$ can provide (at the same cost and requiring no more guarantees than the rest of population) all the external resources $\left(l_{\mathrm{W}}\right)$ demanded for developing E's entrepreneurial idea. Persons $\mathrm{W}$ also have an entrepreneurial idea for using the same resources.

In this first case, the creditors’ priorities list does not play any role because there is only one possible creditor, so $d=0$. Then, strictly speaking, only three kinds of arrangements can appear: market, sole-proprietorship without $\left(k_{\mathrm{i}}=0\right)$ and with capital $\left(k_{\mathrm{i}}>0\right)$. We refer to these solutions as market, sole-proprietorship $\left(k_{\mathrm{i}}=0\right)$ and corporation $\left(k_{\mathrm{i}}>0\right)$. The reason for this notation is that when we extend the model to include persons of type $\mathrm{W}_{1}$ (Version 2) in the population, we show that a list of creditors' preferences reduces the capital requirements of the firm $\left(k_{\mathrm{i}}\right)$, so that $d>0$. Thus, in those cases, corporations would be established whenever $k_{\mathrm{i}}>0$. In other words, the corporation will 
be created with the minimum social capital required, and only when capital is strictly necessary to create the firm. The remaining features of the first version's solution are maintained. This second version can be understood as an extension of the first version, with the only difference that now Persons $\mathrm{W}$ cannot provide all of the external resources demanded for developing E’s entrepreneurial idea. So the entrepreneurial project requires financial support from people even less confident in it than is Person W.

We must note that, in the first version of the model, there is a bilateral negotiation between $\mathrm{E}$ and $\mathrm{W}$. In order to provide a solution, we need to exogenously specify the agents' bargaining power (for convenience, we consider that Person W's bargaining power is $t \in[0,1])$. Thus, Person $\mathrm{W}$ appropriates a wealth equal to $t$ times the expected wealth created by the firm, according to his beliefs. When we extend the model to more agents competing for a job (Version 2), the entrepreneur appropriates all of the wealth.

\section{Model version 1: Main results}

In this section, we assume that the number of agents in the economy is two, Person E and Person W. We characterize Pareto-optimal contracts among credible ones. Pareto-optimal contracts are those under which none of the agents can improve without worsening the other, and credible contracts are understood to be those that can be fulfilled according to both persons' beliefs. We consider more than two agents in Model 2, Section 4, where payment guarantees are used to analyze the optimal legal form of the firm.

\subsection{Main propositions}


First, assuming that the wealth constraint corresponding to $\mathrm{E}$ is not binding, we relate the optimal income share with the allocation of decision rights (Proposition 1), reproducing Van den Steen's (2010a) results. Second, we discuss how wealth constraints can affect the legal form of the firm (Proposition 2).

From the assumptions made in Section 2, it is plain to see that E and W will prefer the market solution to any other solution if they believe that team production is not more productive than is working separately, $l_{\mathrm{E}}+l_{\mathrm{W}} \geq \hat{q}_{E} \geq \hat{q}_{W}$. In such a case, each person keeps property rights, i.e., (i) the authority to choose how to use the corresponding inputs (time), as well as (ii) the right to appropriate the output. Then, a necessary condition for the existence of joint production is that at least one agent believes that team production will generate more wealth than will the market solution, $\hat{q}_{E}>l_{\mathrm{E}}+l_{\mathrm{W}}$. From now on, we assume that $\hat{q}_{E}>l_{\mathrm{E}}+l_{\mathrm{W}}$.

Furthermore, differences in beliefs will also have implications on the income share. In fact, authority implies that Person E will appropriate the entire output. The following proposition summarizes these ideas.

Proposition 1: If $\mathrm{E}$ has no financial constraints ( $m_{\mathrm{i}}$ is high enough), joint production, where E assumes the authority and appropriates the whole output, is the optimal agreement. Otherwise, the market solution is the preferred one (recall that $\hat{q}_{E}>\hat{q}_{W}$ ).

Proof: Given that $\hat{q}_{E}-\hat{q}_{W}>0$ and $\hat{q}_{E}-\left(l_{E}+l_{\mathrm{W}}\right)>0$, the set of Pareto equilibria is necessarily reached by means of joint production following E’s instructions, because it makes it possible to attain the maximum output among the feasible ones. Thus, the expected welfare associated with any other way of organizing 
the production can be improved by the two agents (taking into account that by means of lateral payments from $\mathrm{E}$ to $\mathrm{W}$ the latter one can also get better).

In particular, the set of sharing-rules of output where $\mathrm{E}$ and $\mathrm{W}$, respectively, appropriate $\hat{q}_{E}-l_{\mathrm{W}}-t$ and $s_{\mathrm{W}} \quad l_{\mathrm{W}}+t$, with $\hat{q}_{E}-l_{E}-l_{W}>t>\hat{q}_{W}-l_{E}-l_{W}$, is Pareto optimal, and the Pareto frontier is thus parameterized by $t$. Parameter $t$ indicates the rents that Person $\mathrm{W}$ expects to appropriate (in accordance with his beliefs and the arrangements finally established). Then, it is optimal for $\mathrm{E}$ and $\mathrm{W}$ that the last one renounces authority and the first one assumes it. On the other hand, the wealth attainable also depends on who appropriates the output; one should take into account that sharing an output which has a greater value for $\mathrm{E}$ than for $\mathrm{W}$ cannot be Pareto optimal, because it can be improved by paying $\mathrm{W}$ a fixed salary.

When $l_{\mathrm{E}}+l_{\mathrm{W}}>\hat{q}_{i}$ for all $i$, the market is the solution preferred by both agents. In the market solution, each person has the authority to choose how to use their own inputs (time), they obtain the consequences of their actions $w_{\mathrm{i}}=$ $l_{\mathrm{i}}$, and there is no need for delaying consumption, so $k_{\mathrm{i}}=0$. All of the agents believe that those payments can be made and nobody can improve their utility without harming the others. Then, a necessary condition for the existence of a firm is that at least one agent believes that a firm will generate more wealth than will the market solution, $\hat{q}_{E}>\hat{q}$.

Therefore, differences in beliefs influence the optimal way of sharing the joint output. When Person E has no financial constraints and $\hat{q}_{E}>l_{\mathrm{E}}+l_{\mathrm{W}}$, we have seen that W prefers to totally renounce sharing the (ex-post) output. The reason is simple: he can improve his welfare by renouncing authority, which implies that E will take decisions 
that (according to W's beliefs) are not the best ones. Then W will prefer an ex ante fixed payment rather than sharing the future output, and the output will be appropriated by the agent with authority.

So, at this point we can identify $\mathrm{E}$ as an entrepreneur who keeps the property rights, while $\mathrm{W}$ is identified as an employee who follows the entrepreneur's instructions, earning an ex-ante fixed salary.

It is worth noting that Proposition 1 is silent about $k_{E}$ and, consequently, about the legal form that the common enterprise adopts, i.e., whether it becomes a corporation or a sole-proprietorship business. This occurs because E has unlimited initial wealth. As shown above, when $\hat{q}_{E}>l_{\mathrm{E}}+s_{\mathrm{W}}$, the set of contracts satisfying (i), the output is appropriated by $\mathrm{E}\left(p_{E}=1-p_{W}=1\right)$ and (ii) wages fulfill $\hat{q}_{E}-l_{\mathrm{E}} \geq s_{\mathrm{W}}=-s_{\mathrm{E}} \geq l_{\mathrm{W}}$, then is Pareto optimal. However, without companies $\left(k_{E}=0\right)$ and whenever E's initial wealth is finite, the contract may not be credible for $\mathrm{W}$. The reason is that $\mathrm{W}$ could believe that $\mathrm{E}$ will not be able to fulfill the commitments she has acquired. In particular, he may believe that the output will be smaller than the salary committed to at the beginning of the relationship, $\hat{q}_{W}\left(a_{E}\right)<s_{W}$. In this case, the worker will require legal guarantees to ensure that he will receive his salary, $s_{W}$; for example, through the constitution of a firm

with initial capital $k_{E} \geq s_{W}-\hat{q}_{W}\left(a_{E}\right)>0$. The following result analyzes the determinants of the legal form adopted by the common enterprise.

\section{Proposition 2:}

(a) E will become a sole proprietor if $\mathrm{W}$ believes that by following E's instructions the team can attain a certain level of output $\left(\hat{q}_{W}\left(a_{E}\right) \geq s_{W}\right)$. Otherwise, E will create a corporation whenever her initial wealth is sufficiently large $\left(m_{E} \geq s_{W}-\hat{q}_{W}\left(a_{E}\right)\right)$. 
(b) If $\mathrm{E}$ does not have enough initial wealth $\left(\mathrm{m}_{\mathrm{E}}<s_{W}-\hat{q}_{W}\left(a_{E}\right)\right)$ and $\mathrm{W}$ believes that, following his instructions, team production will attain a certain level $\left(\hat{q}_{W}\left(a_{W}\right)>l_{\mathrm{E}}+\right.$ $s_{\mathrm{W}}$ ), then $\mathrm{W}$ will become a sole proprietor whenever E believes that by following W's instructions the team will attain a certain level of output $\left(\hat{q}_{E}\left(a_{W}\right) \geq s_{\mathrm{E}}\right)$. Otherwise, W will create a corporation whenever his initial wealth is sufficiently large $\left(\mathrm{m}_{\mathrm{W}} \geq s_{\mathrm{E}}-\hat{q}_{E}\right.$ $\left.\left(a_{W}\right)\right)$.

(c) If none of the conditions above hold, it is impossible for $\mathrm{W}$ to get a positive rent $t$ (with $s_{\mathrm{W}}=l_{\mathrm{W}}+t$ ), and the market solution will arise.

Proof: Immediate from the exposition above.

\subsection{Implications: The legal form of the firm depending on W's negotiation power}

A firm becomes an arrangement whereby the two people perform the best actions according to one person's beliefs (henceforth, the entrepreneur), while the other person accepts the entrepreneur's authority (the worker). From Proposition 1, this arrangement is optimal because both agents maximize their respective welfares: the entrepreneur by means of appropriating a superior rent than by working on behalf of $\mathrm{W}$ or working by herself; the worker, by receiving a fixed salary that beats any other kind of compensation available, thus renouncing authority and ex-post income share, i.e., renouncing property rights. Otherwise, the market solution arises (everybody acts according to their own beliefs, owning a business without employees).

Proposition 2 establishes the conditions for the existence of the different arrangements considered as firms: E being a sole proprietor or creating a corporation, and $\mathrm{W}$ being a sole proprietor or creating a corporation. The solution depends on the 
confidence in the other one's project, on one's own wealth, and on their bargaining power. Figure 3 summarizes all of these situations.

\section{Figure 3. The firm's legal form}

E as entrepreneur

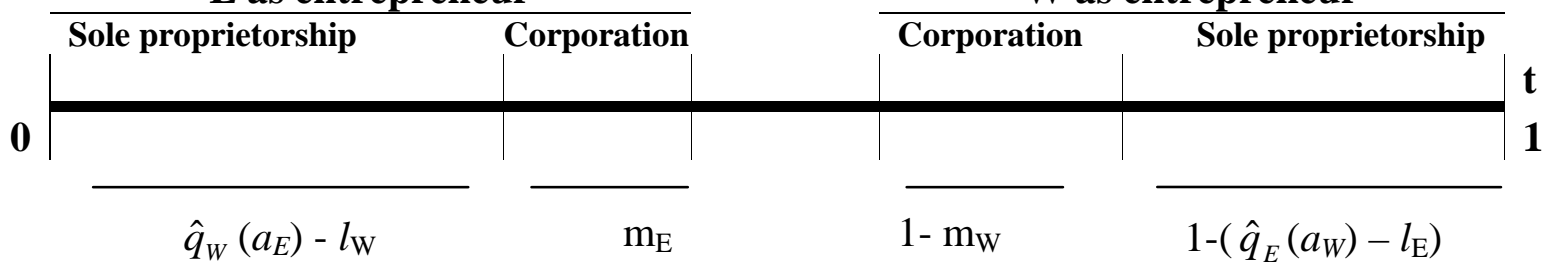

Assumption: $\hat{q}_{W}-\hat{q}>0$.

In a two-person economy, the final agreement is the result of a bilateral bargaining process between $\mathrm{E}$ and $\mathrm{W}$. So, to construct Figure 3, variables have been expressed in terms of the maximum rent that joint production can generate according to W's beliefs: $\hat{q}_{W}-l_{E}-l_{\mathrm{W}}=1$.

When the exogenous bargaining power $(t)$ is lower than or equal to W's confidence in E's project (measured as $\left.\phi_{W}\left(a_{E}\right)-l_{\mathrm{W}}\right)$, E becomes a sole proprietor $\left(t=\mathrm{s}_{\mathrm{W}}\right.$ - $\left.l_{\mathrm{W}} \leq \phi_{W}\left(a_{E}\right)-l_{\mathrm{W}}\right)$. Otherwise, E needs to provide some payment guarantees (social capital: $\left.k_{\mathrm{E}} \geq \mathrm{s}_{\mathrm{W}}-\hat{q}_{W}\left(a_{E}\right)=t-\left(\hat{q}_{W}\left(a_{E}\right)-l_{\mathrm{W}}\right)>0\right)$. Then, she will establish a corporation whenever she has enough wealth to do so, $m_{\mathrm{E}}+\hat{q}_{W}\left(a_{E}\right)-l_{\mathrm{W}} \geq t$. Taking into account that, in general, nothing imposes that $\hat{q}_{W}\left(a_{E}\right)-l_{\mathrm{W}}<1$ or that $m_{\mathrm{E}}+\hat{q}_{W}\left(a_{E}\right)-l_{\mathrm{W}}<1$. In the first case ( $\left.\hat{q}_{W}\left(a_{E}\right)-l_{\mathrm{W}}>1\right)$, only E will appear as a sole proprietor, and in the second one $\left(m_{\mathrm{E}}>1-\hat{q}_{W}\left(a_{E}\right)+l_{\mathrm{W}}>0\right) \mathrm{E}$ will be the entrepreneur, adopting one or another form 
for the firm depending on the worker's (W) bargaining power, in other words, sole proprietorship when $\hat{q}_{W}\left(a_{E}\right)-l_{\mathrm{W}}>t$, and a corporation otherwise.

Obviously, in those cases where E cannot be the entrepreneur because of her wealth limitations, $\left(m_{\mathrm{E}}+\hat{q}_{W}\left(a_{E}\right)-l_{\mathrm{W}}<t\right)$, W has the opportunity to become the entrepreneur (in this case, $t=1-s_{\mathrm{E}}$ ). Then, W will be a sole proprietor if E trusts in W's project, $\hat{q}_{E}\left(a_{W}\right)-l_{\mathrm{E}}$, expecting that $\mathrm{W}$ will assure her salary (whenever $\mathrm{s}_{\mathrm{E}}=1-t \leq \hat{q}_{E}$ $\left.\left(a_{W}\right)-l_{\mathrm{E}}\right)$. In the cases where such confidence is not high enough $\left(\mathrm{s}_{\mathrm{E}}=1-t>\hat{q}_{E}\left(a_{W}\right)-\right.$ $l_{\mathrm{E}}$ ), W will need to offer payment guarantees to $\mathrm{E}$ (who becomes the worker in this case) by creating a corporation with $k_{\mathrm{W}} \geq \mathrm{s}_{\mathrm{E}}-\left(\hat{q}_{E}\left(a_{W}\right)-l_{\mathrm{E}}\right)$. Those guarantees can only be offered if $\mathrm{W}$ has sufficient wealth, $\left(\mathrm{s}_{\mathrm{E}}=1-t \geq m_{\mathrm{W}}+\left(\hat{q}_{E}\left(a_{W}\right)-l_{\mathrm{E}}\right)\right)$; otherwise, $\mathrm{W}$ cannot obtain any positive rent $t$. If Person $W$ cannot obtain a positive rent $\left(m_{\mathrm{E}}+\hat{q}_{W}\right.$ $\left(a_{E}\right)-l_{\mathrm{W}}<0$ and $\left.m_{\mathrm{W}}+\hat{q}_{E}\left(a_{W}\right)-l_{\mathrm{E}}<0\right)$, then the market solution arises.

We have solved the model extending the set of possible actions to more than two (results available upon request), and relaxing the restrictions concerning the value of the model parameters: the firm's establishment costs $(c>0)$, and that the person who eventually develops the idea (and manages the business) is more confident in the project's results $\left(\hat{q}_{W}>\hat{q}_{E}\left(a_{\mathrm{W}}\right)\right)$. Although more complications can be added to the analysis, the main intuitions of the basic model remain.

\section{Model version 2: Several creditors}

Let us now consider a population with a Person E $(i=1)$ and a number of persons of type $\mathrm{W}_{1}(i=2,3, \ldots)$. For expositional simplicity, let us also assume that $l_{\mathrm{i}}=l$ for all $i$. Person E believes that production can be improved, $\hat{q}_{E}>\hat{q}$, if two persons of type $\mathrm{W}_{1}$ (from now on, Persons 2 and 3) change their actions, but $\hat{q}_{E}$ does not depend on who 
the persons of type $\mathrm{W}_{1}$ are that change their actions. But a certain person of type $\mathrm{W}_{1}$ (Person 2 from now on) is more confident in E's entrepreneurial project than in others, $\hat{q}_{E}>\hat{q}>\hat{q}_{i=2}\left(a_{\mathrm{E}}\right)>\hat{q}_{i>2}\left(a_{\mathrm{E}}\right)$.

We also assume that $m_{\mathrm{E}}>\hat{q}-l_{E}=2 l>\hat{q}_{i>2}\left(a_{\mathrm{E}}\right)$. From Propositions 1 and 2, all of these assumptions are equivalent to assuming that (i) Person E will be the entrepreneur of a firm with two workers, persons of type $\mathrm{W}_{1}$, and (ii) she has to provide capital to the entrepreneurial activity, $k_{\mathrm{E}}>0$. In this section our attention is focused on the minimum capital $\left(k_{\mathrm{E}}\right)$ needed to start the firm, assuming that all of the contracts are publicly known.

As a starting point, let us consider the situation in that $l \geq \hat{q}_{2}\left(a_{\mathrm{E}}\right)>\hat{q}_{i>2}\left(a_{\mathrm{E}}\right)$ $\geq 0$. This is the case where the entrepreneur has to pay the maximum possible amount of money at Period 0, i.e., the sum of workers' wages: $k_{E}^{\operatorname{Max}}=\sum_{i=2,3} s_{i}=\sum_{i=2,3} l_{i}=2 l$. Otherwise, the contracts would not be credible from the workers' point of view.

When $\hat{q}_{2}\left(a_{\mathrm{E}}\right)>l$, the amount advanced by the entrepreneur at Period 0 can be reduced to some extent, $k_{E}^{M a x}-k_{E}>0$, which is paid at Period 1 . The minimum amount of capital needed to make the contracts credible for all creditors is:

$$
k_{E}=f l+\left(2 l-\hat{q}_{2}\left(a_{\mathrm{E}}\right)\right) h .
$$

The variables $f$ and $h$ are dummy variables: $h$ takes the value of 1 if $2 l-\hat{q}_{2}\left(a_{\mathrm{E}}\right) \geq$ 0 , and 0 otherwise. The variable $f$ takes the value of 1 if $\hat{q}_{i>2} \leq l$, and 0 otherwise. If $f$ $=1$ and $h=1$, the contract establishes that worker Person 3 will receive his salary at Period 0. When $f=0$ and $h=1$, worker Person 3 will receive $\left(2 l-\hat{q}_{2}\left(a_{\mathrm{E}}\right)\right)$ at Period 0 together with the guarantee that he will be the first creditor to be paid at Period 1 . The total debt of the entrepreneur will be $\hat{q}_{2}\left(a_{\mathrm{E}}\right)>l$, so this contract is credible according to 
the beliefs of Persons 2 and 3 . When $f=0$ and $h=0$, the capital needed to create the firm is zero whenever Person 3 has priority as a creditor. If Person 3 does not have priority as a creditor, the contracts above are not credible and the entrepreneur has to advance more money. In summary, the remaining persons of type $\mathrm{W}_{1}$ can be considered perfect substitutes of Person 2 as workers, but not as creditors.

Corporation laws can be seen as rules providing mechanisms which (i) guarantee that creditors have priority over entrepreneurs in the distribution of output; (ii) establish priorities among the creditors and (iii) guarantee that firms make public such information, i.e., credits and priorities.

From the arguments above, the advanced payments needed by a sole proprietor $\left(k_{\mathrm{E}}{ }^{\mathrm{SP}}\right)$ to develop the firm will be greater than (or at least equal to) those required by a corporation ( $k_{\mathrm{E}}$, and $d=k_{\mathrm{E}}^{\mathrm{SP}}-k_{\mathrm{E}} \geq 0$ ). The arguments above can be summarized in the following result.

Proposition 3: Consider an entrepreneur (E) who has to advance some money to establish a firm, $k_{E}^{M a x}$. If the establishment costs of the corporation are sufficiently low, E will adopt the corporation as the legal form. Otherwise, sole proprietorship will be chosen.

Proof: The costs corresponding to the corporation can be expressed as the legal establishment costs (c) plus the social financial costs of capital $\left(\mathrm{R} k_{\mathrm{E}}\right): c+\mathrm{R} k_{\mathrm{E}}$. The cost of adopting the sole proprietorship legal form is $\mathrm{R} k^{\mathrm{SP}}$, the social financial cost of the money given in advance.

So, when guarantees are required by creditors, such guarantees will be provided in the cheapest way: a corporation if $\mathrm{R} d>c$; a sole proprietorship 
otherwise. If the legal costs are low enough, $c<c_{M A X}=\mathrm{R} d$, a corporation will be preferred rather than a sole proprietorship. Thus, $c_{\text {MAX }}$ establishes a threshold up to which the corporation is the preferred legal form of the firm.

\section{Empirical Implications}

The model predicts that differences in the stakeholders' confidence regarding entrepreneurial projects would affect the internal financial support needed, favoring the existence of a public creditors' priority list. If the legal form is interpreted as a proxy of the existence of such a list of creditors, the model has implications in the adoption of the legal form of the firm.

This topic has scarcely been analyzed from the empirical point of view. Previous studies have used differences in taxes (Gentry and Hubbard, 2000; Schuetze, 2000; Bruce, 2000) or bankruptcy regimes (Fan and White, 2003) to empirically explain the adoption of the legal form of businesses by entrepreneurs. Cole (2011) empirically relates the adoption of the legal form to the financial structure of the business; some of his evidence can be interpreted, using our model.

The model has been developed under the assumption that all firms have the same number of employees. But it is easy to extend the arguments to the case in which there are greater differences in confidence levels among stakeholders when projects are bigger. If bureaucratic costs do not increase with scale (so they are approximately similar for all of the firms empirically compared), the model predicts a positive relationship between the size of the firm and "corporation” as the legal form adopted.

The most intrinsic prediction of the model is that, even when we control for the number of employees, we should expect differences in the way that firms will be financially supported. In this case, the first prediction is that corporations will have higher levels of owners' financial support or capital. This is due to the fact that 
differences in confidence between the entrepreneur(s) and the rest of the stakeholders are higher. One way to reduce such needs of capital, so that the firm be established as "sole-proprietorship", is that the entrepreneur(s) select creditors among those more confident in the entrepreneurial project, such as friends or family. In this case, we expect that corporations will be (relatively) less financially supported by family and friends. This is also consistent with Storey's (1994) evidence that corporations are relatively more financed by banks. Furthermore, the model predicts that, in sole proprietorships, the owner gets financial support by advancing payments to the stakeholders (and corporations will have higher liabilities and will be less financially constrained).

A key prediction of the model is that those differences in financing are related to differences in beliefs (or confidence in the entrepreneurial project). Some personal features of the entrepreneur or the entrepreneurial project can be associated with greater differences in confidence. This could be the case with the education of the entrepreneur or the use of tangible versus intangible assets. The fact that entrepreneurial projects proposed by more educated people (or using a large proportion of intangible assets) are more difficult to evaluate implies the expectation of higher differences in confidence in the projects suggested. This demands for the development of further empirical research that evaluates the role of these features and others, like risk-aversion or optimism.

Finally, the model remains silent about the performance of the firm. Frankish et al. (2013) provide some evidence relating the lifespan of the firm with its legal form. If entrepreneurs do not change their beliefs, due to constant losses along time, those firms with higher capital (i.e., corporations) are expected to last longer.

\section{Conclusions and Extensions}


This paper shows, in a very simple and integrated way, that differences in beliefs regarding the optimal use of productive inputs can explain a broad array of features frequently considered as defining features of the firm: well-defined decision-making authority; concentration of property rights in the entrepreneur; the need for personal wealth to establish firms; the effect of creditors' priorities on the entrepreneur's initial contribution, and the eventually adopted legal form. This simplicity contrasts with other current theories of the firm (see Gibbons, 2005). Our explanation diverges from previous papers like De Mezza and Southey (1996) and Van den Steen (2010a) in that differences in beliefs are not identified with optimism or risk-appetite, nor do they finally converge into a unified belief. Furthermore, it introduces payment guarantees as a determinant of the financial structure of the firm.

Obviously, the paper leaves many questions open for further research. First, it limits the analysis of the legal form to one feature, the list of creditors' priorities. Legal forms have many other features, so further research is needed to understand the role of those features and the adoption of alternative legal forms as different types of corporations, cooperatives or non-profit organizations, among others.

Second, the paper does not address how beliefs evolve over time. Thus, we do not analyze the origin of differences in beliefs, so the model remains silent on some relevant questions. Entrepreneurial teams or how firms or corporations can stimulate entrepreneurship among their employees are two examples. Another one is the compatibility of differences in beliefs with characteristics of the firm's growth process (such as, for example, decisions regarding the delegation process inside firms, or the separation between ownership and management).

More or less explicitly, our model assumes that differences in beliefs remain important along time, so this will also be the case for the legal form of the firm. Parker's 
(2006) empirical evidence suggests that entrepreneurs only partially update their prior beliefs to new information/data. Additionally, there are theoretical arguments suggesting that the convergence in beliefs is difficult.

In fact, in modeling beliefs, we have only considered three elements: actions, predictions and theories (i.e., how persons derive their predictions from the set of actions). We have assumed that they are publicly known, because it is fairly easy to transmit information about actions and predictions regarding their monetary consequences (in fact, it is reasonable to suppose that negotiations are carried out by pooling actions and predictions). Though irrelevant for the present model, this assumption seems much less realistic for the transmission of theories. In fact, humancapital variables used in empirical studies (years of schooling, work experience) have been interpreted as indicators of the time required to learn such theories.

In a more dynamic context, there may be other variables, regardless of people's actions, which may also affect production. In a static model like ours, those variables are irrelevant because their values are given, but in a dynamic context they are likely to play a relevant role. The evolution of the theories, or learning process, is not only affected by the knowledge of the different theories, but also by the information about the actions finally performed by the members of the organization and by other relevant (according to the different theories) variables. As collecting information is expensive, it depends on the knowledge of theories previously acquired. In a context where entrepreneurs or top managers select the information that the firm can generate (and where they have better information about the consequences of workers' actions), it is somewhat unrealistic to think that differences in beliefs will disappear quickly, as soon as production is completed. Furthermore, differences in beliefs can arise because one of the agents thinks in the short-term while the other thinks in the long-term. As long-term 
and short-term benefits are difficult to compare, both agents may well continue to hold divergent beliefs that barely converge over time. Notice that even if people are rational and share the same objectives and historical data, Kurz (1994b) shows that more than one theory might not be rejected by the data. So for all of these reasons (difficulties in learning theories and differences in information), we think that differences in beliefs will persist, and, consequently, that most of our results could be maintained in a dynamic context. 


\section{References}

Aghion, P. and P. Bolton. 1992. “An Incomplete Contracts Approach to Financial Contracting”, Review of Economic Studies, 59: 473-494.

Aghion, P. and P. Bolton. 1997. "A Theory of Trickle-Down Growth and Development”, Review of Economic Studies, 64:151-172.

Aghion, P. and J. Tirole. 1997. "Formal and Real Authority in Organizations", Journal of Political Economy 105: 1-29.

Alchian, A. and H. Demsetz. 1972. "Production, Information Costs, and Economic Organization”, American Economic Review, 62: 777-95.

Arruñada, B. 2012. Institutional Foundations of Impersonal Exchange. Theory and Policy of Contractual Registries. The University of Chicago Press.

Aumann, R. J. 1976. "Agreeing to disagree”, The Annals of Statistics, 4, 1236-1239.

Baron, J.N, M.D. Burton and M.T. Hannan. 1999. "Engineering Bureaucracy: The Genesis of Formal Policies, Positions, and Structures in High-Technology Firms”. Journal of Law, Economics and Organization, 15: 1- 41.

Bertrand, M. and A. Schoar. 2003. "Managing with Style: The Effect of Managers on Firm Policies”, Quarterly Journal of Economics, 143 : 1169- 1208.

Blanchflower D.G. and A.J. Oswald. 1998. "What Makes an Entrepreneur". Journal of Labor Economics, 16: 26-60.

Boot A.W., Gopalan R. and A. Thakor .2006. "The Entrepreneur's Choice between Private and Public Ownership”. The Journal of Finance, 2:803-836.

Boot A.W. and A. Thakor 2011. "Managerial Autonomy, Allocation of Control Rights, and Optimal Capital Structure”. The Review of Financial Studies, 24:3434-3484.

Bruce, D. 2000. "Effects of the United States tax system on transitions into self-employment". Labour Economics, 7: 545-574.

Cantillon, R. 1755 [1955]. In: Higgs, H. (Ed.). Essai sur la Nature du Commerce en Generale. Macmillan, London, p. 1931.

Casson, M. 2005. "Entrepreneurship and the Theory of the Firm". Journal of Economic Behavior \& Organization, 56: 327-348.

Cole, R.A. 2011. "How do Firms Choose Legal Form of Organization?" SBA Office of Advocacy. www.sba.gov/advocacy.

De Meza, D. and C. Southey. 1996. "The Borrower's Curse: Optimism, Finance and Entrepreneurship”. The Economic Journal, 106: 375-386.

Dittmar A. and Thakor A.V.2007. "Why Do Firms Issue Equity”. The Journal of Finance, 1:154.

Drucker, P.F. 1994. "The Theory of the Business”. Harvard Business Review, 72: 95- 104.

Easterbrook, F.H. and D.R. Fischel. 1989. "The Corporate Contract”. Columbia Law Review, 89: $1416-48$.

Evans, D.S. and B. Jovanovic. 1989. "An Estimated Model of Entrepreneurial Choice under Liquidity Constraints”. Journal of Political Economy, 97: 808-27.

Evans, D.S. and L.S. Leighton.1989. ”Some Empirical Aspects of Entrepreneurship”. American Economic Review, 79: 519-35.

Fairlie R.W. 1999. "The Absence of the African-American Owned Business: An Analysis of the Dynamics of Self-Employment”. Journal of Labor Economics, 17: 80-108.

Fan, W. and White, M.J. 2003 "Personal Bankruptcy and the Level of Entrepreneurial Activity". Journal of Law and Economics, XLVI: 543- 567.

Frankish, J., R. Roberts, A. Coad, T. Spears, and D. Storey. 2012. "Do entrepreneurs really learn? Or do they just tell us that they do?" Industrial and Corporate Change, 22: 73-106.

Gentry, W.M. and Hubbard, R.G. 2000. "Tax Policy and Entrepreneurial Entry”. American Economic Review, 90: 283-87.

Gibbons, R. 2005. "Four Formal(izable) Theories of the Firm?”, Journal of Economic Behavior \& Organization, 56: 200-245.

Grossman, S and O. Hart. 1986. "The Costs and Benefits of Ownership: A Theory of Vertical and Lateral Integration”, Journal of Political Economy, 94: 691-719. 
Hansmann, H. and Kraakman, R. 2000. “The Essential Role of Organizational Law” The Yale Law Journal, 110: 387-440.

Hansmann, H. and Kraakman, R. 2006. "Law and the Rise of the Firm” Harvard Law Review, 119: 1333-1403.

Hambrick, D.C. and P.A. Mason. 1984. "Upper Echelons: the Organization as a Reflection of Top Managers” Academy of Management Review, 9: 193-206.

Harhoff, D., Stahl, K. and Woywode M. 1998. "Legal form, growth and exit of West German firms-Empirical results for manufacturing, construction, trade and service industries”. The Journal of Industrial Economics, XLVI (4): 453-488.

Hart O. and J. Moore. 1990. "Property Rights and the Nature of the Firm”, Journal of Political Economy, 98: 1119-1158.

Hart O. and J. Moore, J. 2005. "On the Design of Hierarchies”, Journal of Political Economy, 113: 675-702.

Hermalin, B.E. 1999. “The Firm as a Noneconomy: Some Comments on Holmstrom”, Journal of Law, Economics and Organization, 15: 103-106.

Holmstrom B. 1999. "The Firm as a Subeconomy", Journal of Law, Economics and Organization, 15: 74-101.

Holmstrom, B. and P. Milgrom. 1994. "Multitask Principal-Agent Analysis: Incentive Contracts, Asset Ownership and Job Design". Journal of Law, Economics, and Organization, 7: 24-52.

Holtz-Eakin D., D. Joulfaian and H.S. Rosen. 1994. "Entrepreneurial Decisions and Liquidity Constraints". RAND Journal of Economics, 25: 334-47.

Hurst, E. and A. Lusardi. 2004. "Liquidity Constraints, Household Wealth, and Entrepreneurship”, Journal of Political Economy, 112: 319-347.

Kurz, M. 1994a. “On rational belief equilibria”, Economic Theory, 4: 859-876.

Kurz, M. 1994b. "On the structure and diversity of rational beliefs”, Economic Theory 4: 877-900.

Landier, A. and D. Thesmar. 2007. Financial Contracting with Optimistic Entrepreneurs: Theory and Evidence. SSRN Working Paper.

Landier, A. and D. Thesmar (2008). "Financial Contracting with Optimistic Entrepreneurs: Theory and Evidence”. Review of Financial Studies, 22: 117-150.

Lazear, E.P. 2005. "Entrepreneurship”. Journal of Labor Economics, 23: 649-680.

Moskowitz, T. and A. Vissing-Jorgensen. 2002. "The Returns of Entrepreneurial Investments: A Private Equity Premium Puzzle?”. American Economic Review, 92: 745-778.

Parker, S.C. 2006. "Learning about the unknown: How fast do entrepreneurs adjust their beliefs?”. Journal of Business Venturing, 21: 1-26.

Paulson A.L. and R.M. Towsend. 2004. "Entrepreneurship and Financial Constraints in Thailand”. Journal of Corporate Finance, 10: 229-262.

Paulson A.L., R.M. Towsend and A. Karaivanov. 2006. "Distinguishing Limited Liability from Moral Hazard in a Model of Entrepreneurship”. Journal of Political Economy, 114:100-144.

Quadrini, V. 1999. "The Importance of Entrepreneurship for Wealth Concentration and Mobility". Review of Income and Wealth, 45: 1-19.

Robé, J.P. 2011. "The Legal Structure of the Firm". Accounting Economics and Law, 1,1, Article 5.

Rotemberg, J. and G. Saloner. 2000. "Visionaries, Managers, and Strategic Direction”. RAND Journal of Economics, 31: 693-716.

Samuelson, L. 2004. "Modeling Knowledge in Economic Analysis". Journal of Economic Literature, 42: 367-403.

Schumpeter, J.A. 1939. "Business Cycles: A Theoretical, Historical, and Statistical Analysis of the Capitalist Process”. Philadelphia: Porcupine Press.

Schuetze, H.J. 2000. "Taxes, Economic Conditions and Recent Trends in Male SelfEmployment: a Canada-US Comparison”. Labour Economics, 7: 507-544. 
Simon, H.A. 1951. "A Formal Theory of the Employment Relationship”, Econometrica, 19: 293-305.

Storey, D.J. 1994. "The role of legal status in influencing bank financing and new firm growth". Applied Economics, 26:129-136.

Tirole, J. 1999. “Incomplete Contracts: Where do We Stand?”. Econometrica, 67: 741-781.

Van den Steen, E. 2005. "Organizational Beliefs and Managerial Vision”. Journal of Law, Economics, and Organization, 21: 256-283.

Van den Steen, E. 2010a. "Interpersonal Authority in a Theory of the Firm". American Economic Review, 100, 1: 466-490.

Van den Steen, E. 2010b. "Culture Clash: The Costs and Benefits of Homogeneity," Management Science, Vol. 56, No. 10, October, pp. 1718-1738.

Williamson, O.E. 2000. “The New Institutional Economics: Taking Stock, Looking Ahead”, Journal of Economic Literature, 38: 595-613. 


\section{APPENDIX I: FINANCIAL MARKET EQUILIBRIUM AND UTILITY ASSUMPTIONS}

We have assumed that at Period 0 the financial market is in a situation of equilibrium in the sense that persons have no interest to perform (more) lending/borrowing transactions. Let us characterize this equilibrium by a minimum return required for the production activities $r_{\mathrm{M}}$ and the decisions on goods consumption and production assets at Period 0:

Production assets $\left(l_{i}^{0}\right)$. The assets dedicated to production by Person $i$ in Period 0 .

Consumption $\left(m_{i}=A_{i}-l_{i}^{0}\right)$. Non-production assets or goods, those dedicated to consumption by Person $i$ in Period 0 .

Our focus is about decisions on the use of production assets. The distribution of the output generated by production activities at Period 1 implies a monetary income to Person $i$ of $w_{\mathrm{i}}$. Persons value the different production activities according to $w_{\mathrm{i}}-l_{\mathrm{i}}$, where $l_{i}=\left(1+r_{\mathrm{M}}\right) l_{i}^{0}$, and the changes that they will imply in the equilibrium situation described above.

An easy way to grasp all of these assumptions is through the following inter-temporal utility function of the agents ( $u_{i}^{t}$ is the utility at period $\left.t\right)$ :

$$
U_{i}=u_{i}^{0}\left(1+r_{\mathrm{M}}\right)+u_{i}^{1}=\left(A_{i}-l_{i}^{0}+\mathrm{r}_{\mathrm{B}} \mathrm{b}_{i}-\mathrm{r}_{\mathrm{L}} k_{i}\right)\left(1+r_{\mathrm{M}}\right)+\left(w_{i}-\mathrm{b}_{i}(1+\mathrm{r})+k_{i}(1+\mathrm{r})\right) .
$$

The variable $b_{i} \geq 0$ indicates that Person $i$ is borrowing at interest rate $r$. The increase of one euro in consumption increases its utility at Period 0 by $\mathrm{r}_{\mathrm{B}}$. The variable $k_{\mathrm{i}} \geq 0$ indicates that Person $i$ is lending at interest rate $r$. The decrease of one euro in consumption decreases his/her utility by $\mathrm{r}_{\mathrm{L}}$. When $\mathrm{b}_{i}>0$, then $k_{i}=0$ and vice versa. The market equilibrium implies that $\mathrm{r}_{\mathrm{B}}<1<\mathrm{r}_{\mathrm{L}}$.

Then, we assume that whatever the price of the financial transaction is, $r$, there is a social cost $R=\left(r_{L}-r_{B}\right)\left(1+r_{M}\right)>0$ associated with the fact that one Person $i$ lends one euro to another $-i, k_{i}=\mathrm{b}_{-i}=1$. This is justified in terms of market equilibrium deviance $\left(r_{L}-r_{B}>0\right)$. We assume that all of these costs are assumed by the lender $\left(r_{B}=(1+r)\right.$ $\left./\left(1+r_{M}\right)\right)$. Then utility $U_{i}$ can be written as:

$$
U_{i}=A_{i}\left(1+r_{\mathrm{M}}\right)+u_{i}=A_{i}\left(1+r_{\mathrm{M}}\right)+\left(w_{\mathrm{i}}-l_{\mathrm{i}}-\mathrm{R} k_{\mathrm{i}}\right) .
$$

As we have assumed that $A_{\mathrm{i}}$ and $r_{\mathrm{M}}$ are exogenously given, the different production activities can be compared by Person $i$ in terms of $u_{\mathrm{i}}=w_{\mathrm{i}}-l_{\mathrm{i}}-\mathrm{R} k_{\mathrm{i}}$, the utility function proposed in the paper. 


\section{APPENDIX II: RISK AVERSION AND DIFFERENCES IN BELIEFS}

\section{The general framework}

Following Van den Steen (2010a), actions (in our case, L= $a_{\mathrm{E}}, a_{\mathrm{W}}$ ) can be expressed as random variables (lotteries) with two possible realizations, $\mathrm{V}$ and $\mathrm{v}$, with $\mathrm{V}>\mathrm{v} ; \mathrm{p}_{\mathrm{i}, \mathrm{L}}$ represents the probability associated with $\mathrm{V}$, which can vary depending on the person $(\mathrm{i}=\mathrm{E}, \mathrm{W})$ who values the action. For the sake of simplicity and without loss of generality, we normalize $U_{i}(V)=1$ and $U_{i}(v)=0$ for both persons, where $U_{i}(\cdot)$ represents the utility associated with Person i.

\section{The values associated with different actions}

According to Person i, the value (measured in terms of the certain equivalent CE) of a random variable, $L$, can be expressed as: $C E_{i, L}=U_{i}^{-1}\left(p_{i, L}\right)$. Then, in the case of differences in beliefs $\left(\mathrm{p}_{\mathrm{E}, \mathrm{L}} \neq \mathrm{P}_{\mathrm{W}, \mathrm{L}}\right)$ and risk neutrality we can establish that:

$$
\begin{aligned}
& \mathrm{CE}_{\mathrm{E},} a_{\mathrm{E}}=\mathrm{p}_{\mathrm{E},} a_{\mathrm{E}} \mathrm{V}+\left(1-\mathrm{p}_{\mathrm{E}}, a_{\mathrm{E}}\right) \mathrm{v}=\hat{q}_{\mathrm{E}}, \\
& \mathrm{CE}_{\mathrm{W},} a_{\mathrm{E}}=\mathrm{p}_{\mathrm{W}}, a_{\mathrm{E}} \mathrm{V}+\left(1-\mathrm{p}_{\mathrm{W}}, a_{\mathrm{E}}\right) \mathrm{v}=\hat{q}_{\mathrm{W}}\left(a_{\mathrm{E}}\right), \\
& \mathrm{CE}_{\mathrm{E},} a_{\mathrm{W}}=\mathrm{p}_{\mathrm{E}}, a_{\mathrm{W}} \mathrm{V}+\left(1-\mathrm{p}_{\mathrm{E}}, a_{\mathrm{W}}\right) \mathrm{v}=\hat{q}_{\mathrm{E}}\left(a_{\mathrm{W}}\right), \text { and } \\
& \mathrm{CE} \mathrm{W}_{\mathrm{W}} a_{\mathrm{W}}=\mathrm{p}_{\mathrm{W}}, a_{\mathrm{W}} \mathrm{V}+\left(1-\mathrm{p}_{\mathrm{W}}, a_{\mathrm{W}}\right) \mathrm{v}=\hat{q}_{\mathrm{W}} .
\end{aligned}
$$

But different values of the lotteries ( $\hat{q}_{E}, \hat{q}_{\mathrm{W}}\left(a_{\mathrm{E}}\right), \hat{q}_{\mathrm{E}}\left(a_{\mathrm{W}}\right)$ and $\left.\hat{q}_{W}\right)$ can also be obtained when there are no differences in beliefs, $\mathrm{p}_{\mathrm{E}, \mathrm{L}}=\mathrm{p}_{\mathrm{W}, \mathrm{L}}=\mathrm{p}_{\mathrm{L}}$, but rather there are differences in the utility function of the agents:

$$
\begin{aligned}
& \hat{q}_{\mathrm{E}}=\mathrm{CE}_{\mathrm{E},} a_{\mathrm{E}}=\mathrm{U}_{\mathrm{E}}^{-1}\left(\mathrm{p} a_{\mathrm{E}}\right), \\
& \hat{q}_{\mathrm{W}}\left(a_{\mathrm{E}}\right)=\mathrm{CE}_{\mathrm{W},} a_{\mathrm{E}}=\mathrm{U}_{\mathrm{W}}^{-1}\left(\mathrm{p} a_{\mathrm{E}}\right), \\
& \hat{q}_{\mathrm{E}}\left(a_{\mathrm{W}}\right)=\mathrm{CE}_{\mathrm{E},} a_{\mathrm{W}}=\mathrm{U}_{\mathrm{E}}^{-1}\left(\mathrm{p} a_{\mathrm{W}}\right) \text { and } \\
& \hat{q}_{\mathrm{W}}=\mathrm{CE}_{\mathrm{W}}, a_{\mathrm{W}}=\mathrm{U}_{\mathrm{W}}^{-1}\left(\mathrm{p} a_{\mathrm{W}}\right) .
\end{aligned}
$$

\section{The difference: Disagreement in the social welfare.}

In the case where there are no differences in beliefs, $\mathrm{p}_{\mathrm{E}, \mathrm{L}}=\mathrm{p}_{\mathrm{W}, \mathrm{L}}=\mathrm{p}_{\mathrm{L}}$, but there are differences in the utility functions, $\mathrm{W}$ agrees with $\mathrm{E}$ in the social welfare generated by the actions ( $\left.\mathrm{L}=a_{\mathrm{E}}, a_{\mathrm{W}}\right)$. For example, in the case that lottery $a_{\mathrm{E}}$ is played by Person $\mathrm{E}$, both agree that the social welfare will be:

$\hat{q}_{E}=\mathrm{CE}_{\mathrm{E}}, \quad a_{\mathrm{E}}=\mathrm{U}_{\mathrm{E}}^{-1}\left(\mathrm{p} a_{\mathrm{E}}\right)$, 
but this will not be the case when there are differences in beliefs and risk neutrality.

Analogously, when lottery $a_{\mathrm{E}}$ is played by Person E:

Social welfare for $\mathrm{W}$ will be equal to $\mathrm{p}_{\mathrm{W}}, a_{\mathrm{E}} \mathrm{V}+\left(1-\mathrm{p}_{\mathrm{W}}, a_{\mathrm{E}}\right) \mathrm{v}=\hat{q}_{\mathrm{W}}\left(a_{\mathrm{E}}\right) \neq \mathrm{p}_{\mathrm{E}}, a_{\mathrm{E}} \mathrm{V}+$ $\left(1-\mathrm{p}_{\mathrm{E}}, a_{\mathrm{E}}\right) \mathrm{v}=\hat{q}_{E}=$ social welfare according to $\mathrm{E}$.

Similar arguments can be replicated by changing the action and/or the person.

So, what we assume is that persons disagree about the welfare generated by a certain action made by a certain person.

\section{Typology of situations}

a) No differences in beliefs: $\mathrm{CE}_{\mathrm{E}}, a_{\mathrm{E}} \geq \mathrm{CE}_{\mathrm{E},} a_{\mathrm{W}}$ and $\mathrm{CE}_{\mathrm{W}}, a_{\mathrm{E}} \geq \mathrm{CE}_{\mathrm{W}}, a_{\mathrm{W}}$ or $\mathrm{CE}_{\mathrm{E},} a_{\mathrm{E}} \leq \mathrm{CE}_{\mathrm{E},} a_{\mathrm{W}}$ and $\mathrm{CE}_{\mathrm{W}}, a_{\mathrm{E}} \leq \mathrm{CE}_{\mathrm{W}}, a_{\mathrm{W}}$

In this case, both persons have the same preferences about actions. So, in a certain way, the output of the firm can be modeled as is usual in agency theory: a single lottery. There can be risk-neutral agents $\left(\mathrm{CE}_{\mathrm{E},} a_{\mathrm{E}}=\mathrm{CE} \mathrm{W}_{\mathrm{E}} a_{\mathrm{E}}\right.$ and $\left.\mathrm{CE}_{\mathrm{E},} a_{\mathrm{W}}=\mathrm{CE} \mathrm{W}_{\mathrm{W}}, a_{\mathrm{W}}\right)$ or those without differences in terms of risk preferences $\left(\mathrm{CE}_{\mathrm{E}}, a_{\mathrm{E}} \neq \mathrm{CE} \mathrm{W}_{\mathrm{E}}\right)$.

b) Differences in beliefs: The remaining cases.

b1) Optimism. ${ }^{8} \mathrm{CE}_{\mathrm{E}}, a_{\mathrm{E}}>\mathrm{CE} \mathrm{W}_{\mathrm{E}} a_{\mathrm{E}}$ and $\mathrm{CE}_{\mathrm{E}}, a_{\mathrm{W}}>\mathrm{CE}_{\mathrm{W}}, a_{\mathrm{W}}$ or

$$
\mathrm{CE}_{\mathrm{E},} a_{\mathrm{E}}<\mathrm{CE}_{\mathrm{W}}, a_{\mathrm{E}} \text { and } \mathrm{CE}_{\mathrm{E},} a_{\mathrm{W}}<\mathrm{CE}{ }_{\mathrm{W}}, a_{\mathrm{W}}
$$

b2.1) Differences in confidence: ${ }^{9} \mathrm{CE}_{\mathrm{E}}, a_{\mathrm{E}}>\mathrm{CE}_{\mathrm{W}}, a_{\mathrm{W}}$ or $\mathrm{CE}_{\mathrm{E}}, a_{\mathrm{E}}<\mathrm{CE}{ }_{\mathrm{W}}, a_{\mathrm{W}}$.

b2.2) No differences in confidence: $\mathrm{CE}_{\mathrm{E}}, a_{\mathrm{E}}=\mathrm{CE} \mathrm{W}_{\mathrm{W}} a_{\mathrm{W}}$

\footnotetext{
8 De Meza and Southey (1996) is not a model of differences in beliefs. So, in their case, it is quite difficult to distinguish between optimism and differences in risk preferences.

${ }^{9}$ As defined by Van den Steen (2010a).
} 


\section{Beliefs about beliefs:}

Furthermore, Van den Steen (2010a) assumes that the firms have been established before beliefs are known by the persons and that beliefs are private information. So before taking some decisions it must be known the joint distribution of probabilities about the beliefs each person has, whether each player has different beliefs about the distributions of such probabilities. At this point the assumptions of the model are:

i) There are no differences in beliefs concerning the joint distribution of beliefs. So both players share the same joint distribution.

ii) Those distributions are independent. The beliefs of one person do not reveal about the beliefs of the other.

iii) Initially, the distribution of probabilities concerning the beliefs that each person has is identical.

With these assumptions, the only possible cases are (a) identical beliefs with riskneutral agents or (b) differences in beliefs with no differences in confidence.

At a second step, Assumption iii) is modified, so at this point the possible cases are (a) equal beliefs with different degrees of risk aversion or (b) differences in beliefs with differences in confidence. 


\section{APPENDIX III: WHY NOT BETTING CONTRACTS?}

We argue that, although workers and entrepreneurs can establish a framework of compromises, the actions may be unverifiable by third parties. Usually, workers and entrepreneurs have better information about the situation of the firm than do third parties before output is finally obtained. When actions are not verifiable, betting contracts favor poor collaboration or even "sabotage" actions (like a fixed boxing match).

Let us extend our basic model to incorporate such arguments. If a firm is created, the timing is as follows:

Agreement:

Market solution.

Firm:

Final output is

i Entrepreneur Observable actions: Information: Sabotage obtained:

-i Worker $a_{\mathrm{i}}$ where $\mathrm{i}=\mathrm{E}$ or $\mathrm{W} \quad \mathrm{I}=\hat{q}_{i}$ or $\mathrm{I}=\hat{q}_{-\mathrm{i}}\left(a_{\mathrm{i}}\right) \quad$ actions:

$\mathrm{d}_{-}=1$ or $\mathrm{d}_{\mathrm{i}}=0$
$\mathrm{Q}=\mathrm{I}-\mathrm{d}-_{\mathrm{i}}\left(\hat{q}_{i}-\hat{q}_{-\mathrm{i}}\left(a_{\mathrm{i}}\right)\right)$

1

\begin{tabular}{|l|l|l|ll}
$\mathbf{2}$ & 3 & 4 & 5 & Stages
\end{tabular}

Before obtaining the final output q (step 5), entrepreneurs and workers have private, and consequently, non-contractible information (Step 3) about how things are. They know whether the firm works in accordance with the entrepreneur's beliefs, I= $\hat{q}_{E}$, or workers' beliefs, $\mathrm{I}=\hat{q}_{-\mathrm{i}}\left(a_{\mathrm{i}}\right)$. Given this information, the worker can decide (Step 4) to collaborate more or less actively with the team; in other words, perform actions to reduce production $\left(\mathrm{d}_{-\mathrm{i}}=1\right)$ or not $\left(\mathrm{d}_{-\mathrm{i}}=0\right)$. Those actions are not verifiable by third parties and, consequently, not contractible. The cost of such actions is practically null and the losses caused to the firm are equal to $\hat{q}_{i}-\hat{q}_{-i}\left(a_{i}\right)$. These five stages are fairly close to those used by Gibbons (2005, Sec. 4) to compare four theories of the firm. As can be checked, the key differences among the cited models are the assumptions about beliefs. The rest of the assumptions have been made before in other models.

In such a situation, a (betting) contract where the entrepreneur pays $\mathrm{L}$ if $\mathrm{q}=\hat{q}_{i}$ and $\mathrm{H}>$ $\mathrm{L}$ if $\mathrm{q}=\hat{q}_{-\mathrm{i}}\left(a_{\mathrm{i}}\right)$ will never be offered by the entrepreneur because, if $\mathrm{I}=\hat{q}_{i}$ in Step 4, the worker would have incentives to perform sabotage actions, so the output obtained is $q=$ 
$\hat{q}_{-i}\left(a_{\mathrm{i}}\right)$ and the final wage is $\mathrm{H}$. Thus, in Step 1 betting contracts can be improved by fixed wages equal to $\mathrm{H}$, because output can be either $\mathrm{q}=\hat{q}_{i}$ or $\mathrm{q}=\hat{q}_{-\mathrm{i}}\left(a_{\mathrm{i}}\right)$. So the solution coincides with the solution of a simplified model with the following three steps (imposing now that betting contracts are ruled out, so there are no incentives for sabotage, $d_{-i}=0$; this is what we do in the main text of the paper):

Agreement:

Market solution.

Firm:

i Entrepreneur Observable actions: Final output is

-i Worker $\quad a_{\mathrm{i}}$ where $\mathrm{i}=\mathrm{E}$ or $\mathrm{W}$ obtained:

$\mathrm{q}=\hat{q}_{i}$ or $\mathrm{q}=\hat{q}_{-\mathrm{i}}\left(a_{\mathrm{i}}\right)$

\begin{tabular}{|l|l|ll}
\hline $\mathbf{1}$ & $\mathbf{2}$ & $\mathbf{3}$ & Stages \\
\end{tabular}

